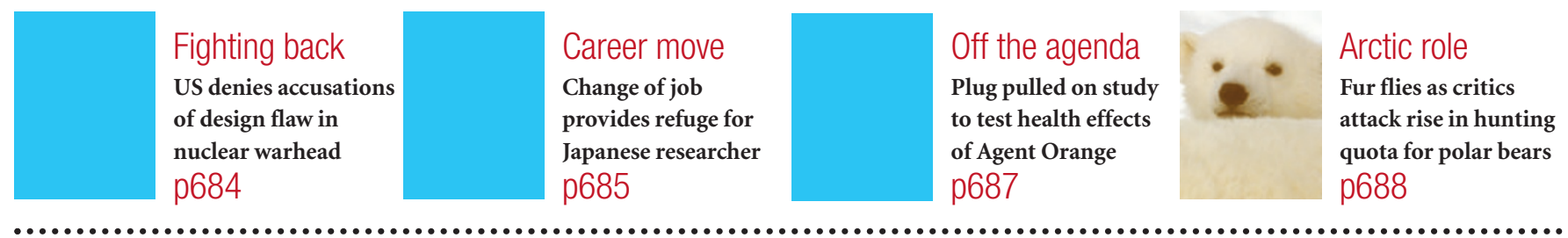

\title{
Warning system steps up a gear for fresh Indonesian earthquake
}

\section{Declan Butler}

Warnings about the risk of a tsunami after the recent earthquake in Indonesia spread faster and more widely than they did for last December's calamitous event, officials in the region say.

The latest earthquake struck off the coast of Sumatra on 28 March, just days before an interim tsunami warning system for the Indian Ocean was due to come into force on 1 April. But warnings were still delivered much more rapidly than they had been in December.

In the event, the magnitude- 8.7 earthquake didn't generate a large tsunami. That was just as well, because when it struck, only a handful of the 25 countries in the interim warning system had provided names and numbers for national points of contact. "The earthquake happened before our deadline for receiving contact points," says Keith Alverson, head of UNESCO's Global Ocean Observing System in Paris.

Under the interim system, the US Pacific Tsunami Warning Center (PTWC) in Hawaii
IMAGE

UNAVAILABLE FOR COPYRIGHT REASONS

quickly and decisively than in December. Shortly after that quake it issued two bulletins - but only to members of the Pacific warning system. One, issued 15 minutes after the event, stated that a quake of magnitude 8.0 had occurred, with no risk of tsunamis to Pacific nations. The second, issued 45 minutes later, upgraded the quake to magnitude 8.5 and stated that there was "the possibility of a tsunami near the epicentre".

The centre's team then also attempted to contact colleagues in Indonesia and Thailand, both members of the Pacific system. It

and the Japan Meteorological Agency will provide alerts on all seismic activity in the Indian Ocean region to round-the-clock contact points in the surrounding countries. The system, agreed in March (see Nature 434, 261;2005), is intended as a stopgap until 2006, when agreement is due on the details of a full-blown warning system based on tide gauges and seafloor pressure monitors.

The PTWC itself responded much more

\section{Plotting the course of a quake}

Researchers are hoping that data collected in the wake of the recent earthquakes in Indonesia will allow them to build better models of the relationship between different seismic events in the region.

Kerry Sieh, for example, a seismologist at the California Institute of Technology in Pasadena, is pulling together data from global positioning system receivers on and around Sumatra. He hopes to study how the land moved before, during and after the 28 March event and the one last December that generated a tsunami.

Data coming in as Nature went to press showed some surprisingly large movements after the March earthquake, such as land at an airport on the nearby island of Simeulue, which rose 1.6 metres and shifted 2.3 metres towards the ruptured fault, says Sieh.

Sieh's data, taken continuously at various locations on the islands near the earthquake fault, should help to resolve a controversy over whether changes in Earth's structure can be seen before an earthquake. Such land 'deformations' were not seen in the run-up to other well-monitored large earthquakes, such as Tokachi-Oki in northern Japan in 2003. Some scientists say that failure to see anything here would be another nail in the coffin for these efforts.

More positive results will probably come from mixing the geological observations with physical modelling of how earthquakes affect the surrounding region. In a 17 March paper in Nature, John McCloskey of the University of Ulster used models of how stress can move down faults to identify areas that could be at risk of rupture following the December earthquake (J. McCloskey, S. S. Nalbant and S. Steacy Nature 434, 291; 2005). McCloskey and Sieh now plan to work together to assess the risks of a rupture on faults south of the recent epicentres. David Cyranoski, Tokyo was four-and-a-half hours before the PTWC sent a message to the Tsunami Bulletin Board — which goes by e-mail to international tsunami scientists and organizations mentioning press reports of the disastrous tsunami.

The reaction was very different this time. Twenty minutes after the earthquake, the PTWC sent out a bulletin simultaneously to Pacific centres and to the bulletin board, warning that the event had "the potential to generate a widely destructive tsunami in the ocean or seas near the earthquake". It explicitly advised evacuating coasts within 1,000 kilometres of the epicentre.

The PTWC also alerted the US Department of State, which sent messages to US embassies in the Indian Ocean region. The embassies, in turn, informed local emergency management agencies. "The PTWC now pays particular attention to the Indian Ocean; last time they weren't looking at it," says Peter Pissierssens, head of ocean services at the Intergovermental Oceanographic Commission in Paris.

But international organizations report that responses to these warnings were patchy. The authorities in some coastal areas did issue prompt alerts and evacuated coastal areas. And vibrations from the earthquake itself were enough to send many people running inland. "There has been some progress in getting a warning system, but not a huge amount,"says Alverson. 